\title{
MORPHOMETRIC AND BIOCHEMICAL ANALYSIS OF YEAST CELLS UNDER LOW TEMPERATURE STORAGE
}

\author{
Aleksandr Shleikin ${ }^{1 *}$, Nadezhda Zhilinskaia ${ }^{2}$, Natalia Skvortsova ${ }^{1}$ \\ ${ }^{1}$ Department of Chemistry and Molecular Biology, Faculty of Food Technologies and Engineering, ITMO University, \\ KronverkskyAv.49, St. Petersburg, 197101, Russia, e-mail: shleikin@yandex.ru \\ ${ }^{2}$ Graduate School of Biotechnology and Food Science, Peter the Great St. Petersburg Polytechnic University, Polytechnicheskaya \\ Str. 29, St.Petersburg, 195251, Russia
}

\begin{abstract}
The aim of the research is to measure thiol compounds as well as glycogen content in yeast cells of different sizes during long-term storage at low temperature. The size, SH-groups and glycogen content changes in the $S$. cerevisiae cells were studied over the period of 35 days storage at $0 \pm 5^{\circ} \mathrm{C}$. The new morphometric method used has showed that the total amount of cells and number of large cells $(7-8 \times 12-15 \mu \mathrm{m})$ remained unchanged when compared with control under model conditions; the number of budding yeasts decreased 4 times, and the number of dead cells increased 2 times during the storage period. The number of middle size cells $(5-7 \times 10-12 \mu \mathrm{m})$ decreased 1.2 times, while the number of small cells $(4-5 \times 7-9 \mu \mathrm{m})$ increased 9.5 times. Under the same conditions the quantity of low molecular SH-groups increased 2 times, while protein-containing SH-groups dropped down by $31 \%$. The content of glycogen decreased 1.2 times. The results elaborated revealed that generally yeasts under unfavorable conditions lose the deposition nutrients such as glycogen and store up the adaptive SH-containing substances. The cells of a large size probably have more high adaptation capacity to long-term storage at low temperature and in the absence of a nutrient medium. The rising amount of small cells and of low molecular SH-groups evidently indicates the development of adaptation state in the yeast population. Future investigations have to find out the range correlations between morphologic parameters of yeast cells and the content of biochemical substances.
\end{abstract}

Keywords: yeast, size of cells, thiols.

\section{Introduction}

Yeast of Saccharomyces cerevisiae species are a source of low-molecular and high-molecular biologically active substances and find varied commercial technological applications. Yeast cultures are also used for modeling physical and chemical processes (Coelho et al., 2013; Schreuder et al., 1996), medical and biological investigations (Ksenzhek, Petrova, 1984; Leung-Toung et al., 2002). Among intracellular yeasts metabolites, thiol containing compounds have a special attention of researchers, especially the water-soluble antioxidant - tripeptide glutathione which accounts for about $90 \%$ of intracellular low-molecular thiols. Glutathione participates in red/ox homeostasis, regulation of enzyme activity and immune responses (Liu et al., 1996; Schafer, Buettner, 2001), protects cell structures against the damaging effects of reactive oxygen species (Müller, Lösche, 2004; Schafer, Buettner, 2001. Thiol-disulfide cellular system is known to be involved in the response of living systems to geophysical, biological and manmade environmental factors (Sokolovskij, 2008). Low-molecular thiols are likely to be cellular detectors with a non-specific reaction to external stimuli by a change in the ratio of reduced to oxidized sulfhydryl groups. Thiol-disulfide exchange reactions of low molecular thiol substances with sulfhydryl groups of protein triggers provide some conformational changes in their three-dimensional structures, which initiates biochemical reactions of adaptation mechanisms (Müller, Lösche, 2004). The paradigm of thiols significance understanding in living systems has recently changed from antioxidant defense to redox regulation of cell functions (Flohe, 2010). Thioredoxins are the most likely key reactive proteins in mechanisms of red / ox cell signaling (Schreuder et al., 1996; Baronian, Gurazada, 2007). Depletion of reduced glutathione and protein thiol oxidation is known to result in an activation of transcription of heart shock protein genes (Petit et al., 1996). In 1950s it was found that aging and stressful situations result in antioxidant depletion in cells and tissues of multicellular organisms, which affects the amount of glutathione, the main thiol intracellular antioxidant, and leads to a decrease of the organism resistance damaging factors (Ksenzhek, Petrova, 1984). Under unfavorable conditions the amount of reduced glutathione in yeasts increases, which makes these organisms different from other cells (Munday, Winterbourn, 1989). An investigation of the accumulation dynamics of reduced low-molecular thiols (mainly, glutathione) as thiol enzyme activators is very interesting for microbiologists, biochemists, enzymologists and biotechnologists. The use of yeast storage methods at low temperatures $0-4{ }^{\circ} \mathrm{C}$ results in a significant change of biochemical characteristics of cultures, which is important for their further research and commercial applications. The changes of antioxidant status in yeast cells used as biosensors may have two implications. Firstly, they can determine the strength of the acting factor, for instance, for environmental monitoring. On the other hand, cells need to be standardized to control their uniformity for obtaining reproducible biosensor signals. This can be achieved by some biochemical tests as well as by some morphological methods due to development of high-performance equipment for cell sorting. The capability of the equipment to analyze a large number of individual cells for several parameters simultaneously has changed the understanding of the behavior of cells in culture and of the population dynamics (Deere et al., 1998, Mattanovich, 
Borth, 2006). The potential of this method for biotechnological research is invaluable.

Thus, the aim of the present study was to observe the ratio of changes of high to low molecular thiols and glycogen content in yeast cultures during long-term storage at low temperatures.

\section{Materials and Methods}

The yeast culture $S$. cerevisiae, species LV-7 was obtained at St. Petersburg food processing plant. The yeasts were stored for 1 day at $0-4{ }^{\circ} \mathrm{C}$. Aliquots of yeast cells were selected every week for microscopic and biochemical investigations. Computer cytophotometry was used for morphometric analysis (Zhilinskaia et al., 2016). To prepare the culture dilutions, yeasts were suspended in a $0.9 \%$ $\mathrm{NaCl}$ solution in the ratios of $1: 10,1: 100$ and $1: 1000$. No nutrients were added to yeast suspension. The living cells were prepared for microscopic analysis using crushed drops method. The presence of glycogen granules in cells was determined by staining the diluted yeast suspension with a Lugol aqueous solution according to the Gram staining method. Microscopic analysis of samples was carried out in visible spectral region using microscope Leica DM LB2 (Germany) with a Leica DFC 320 digital camera providing a total 1000-fold magnification. Images were recorded by video system and displayed on a Pentium 4 computer screen with Leica YM - 1000 software for Windows. Morphometric measurements of yeast cells were carried out using staining samples with Lugol solutions for 36 randomly selected fields of view. The number of cells was counted in Gorjaev chamber, the total number of analyzed cells was more than 1000 . The criteria for morphometric analysis of yeast cells were as follows: the size and shape of cells, budding, the number of dead and budding cells, cytoplasm and organelles, presence of glycogen inclusions. The biochemical analysis included the following procedures: yeast cells walls were frozen at $-20{ }^{\circ} \mathrm{C}$ and quickly unfrozen, homogenized for $5 \mathrm{~min}$ in a Potter-Elvehjem glass homogenizer with distilled water (with yeasts: water ratio of $1: 10)$. The obtained water suspensions were pelleted in a centrifuge for $30 \mathrm{~min}$ at $13000 \mathrm{~g}$ and $+4{ }^{\circ} \mathrm{C}$. The total protein content was determined using Lowry method (Lowry et al., 1951). The lowmolecular sulfhydryl (SH-) and disulfide (SS-) groups were determined using TDA-02 amperometric titrator of the Institute for Analytical Instrumentation of the Russian Academy of Sciences (Sokolovskij, 1962). The concentration of protein SH- and SS-groups in the samples was measured in $\mu \mathrm{mol} \cdot \mathrm{g}^{-1}$, that of low-molecular SH- and SS-groups - in $\mu \mathrm{mol} \cdot \mathrm{L}^{-1}$. Microsoft Excel-2000 was a standard method for statistical data analysis. The difference between the values compared was found to be significant at $\mathrm{p}<0.05$.

\section{Results and Discussion}

The microscopic analysis has shown a heterogeneous yeast cell population. There were revealed large, medium, small and budding living cells in the view field. For a correct analysis, we divided them into three categories. According to their geometrical size the yeast cells were classified into these groups:

1. The large cells (size is $7-8 \times 12-15 \mu \mathrm{m}$ ) were lemon-shaped and had a granular cytoplasm, plenty of vacuoles, thickened cell wall, a clearly contoured large nucleus and a lot of stained glycogen granules.

2. The medium cells (size 5-7 $\times 10-12 \mu \mathrm{m}$ ) were round or lemon-shaped, characterized by a granular cytoplasm and the presence of single stained glycogen granules. Around $47-50 \%$ cells of this group have a thickened cell wall.

3. The small cells $(4-5 \times 7-9 \mu \mathrm{m})$ had ellipsoid shape, a homogeneous cytoplasm, a thin cell wall and small vacuoles without any glycogen granules.

The size of dead yeast cells was smaller than $2-3 \times 5-6 \mu \mathrm{m}$. They were irregularly shaped cells with a condensation of the cytoplasm and the nucleus and vacuoles and no glycogen granules. Some results of morphometric analysis of yeast cells during their storage are presented in the Figure 1.

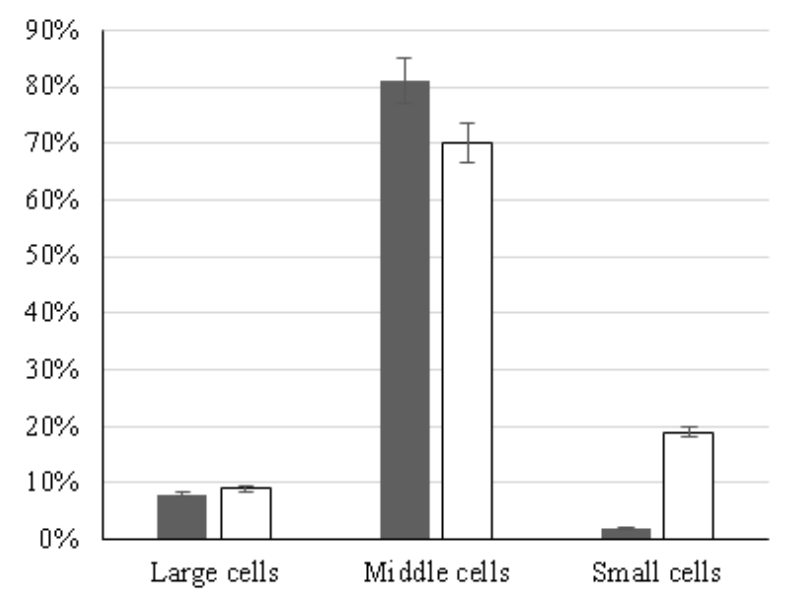

Figure 1. The ratio of the number of large $S$. cerevisiae cells to the number of medium and small cells during storage at low temperatures

- the number of fresh yeast cells after 1 day of storage at $2 \pm 2{ }^{\circ} \mathrm{C}$;

$\square$ - the number of yeast cells after 21 days of storage at $2 \pm 2{ }^{\circ} \mathrm{C}$.

The morphometric analysis of fresh yeast showed that medium cells accounted for $81 \%$, large cells made $8 \%$; small cells took $2 \%$ of the examined yeast population (Fig. 1). $87 \%$ of large cells and $36 \%$ of medium cells contained glycogen granules in cytoplasm. The number of yeast cells in the samples made $2 \%$. The data obtained has shown that there were no dead cells in the samples. Medium sized cells were predominant $(70 \%$ of the total) after 21 days of storage at low temperatures. However, the amount of medium cells after 21 days decreased 1.2 times compared to that in fresh yeast. The number of large cells increased 1.13 times during their storage and made $9 \%$ out of the total cell number. The amount of small cells increased 
9.5 times during their storage and they accounted for $19 \%$ of the total cell number. The presence of glycogen granules in the cytoplasm of $70 \%$ large cells and $30 \%$ medium cells indicated that nutrient reserves of yeast cells decreased 1.2 times during storage (Fig. 2). The small cells had no glycogen granules. The number of budding yeast cells decreased 4 times and made $0.5 \%$ : the number of dead cells doubled and was equal to $2 \%$.

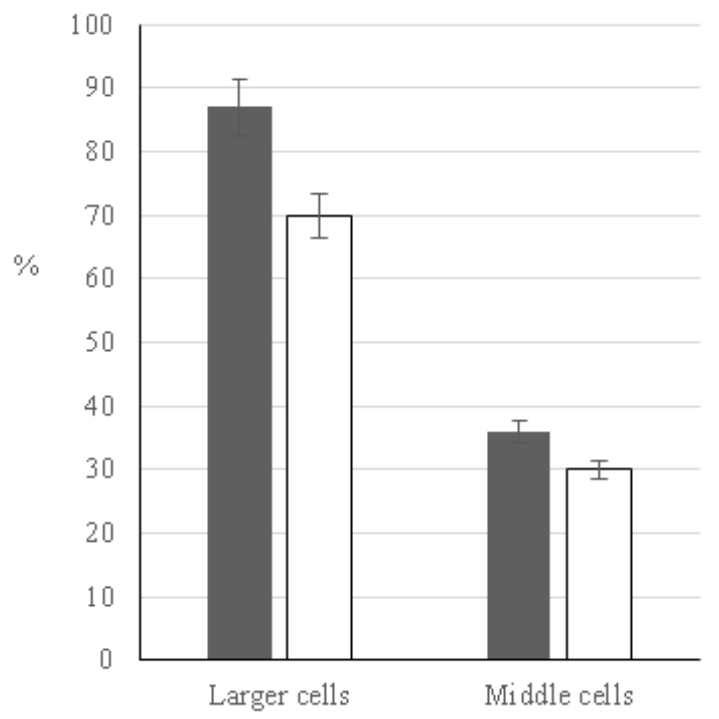

Figure 2. The number of yeast cells S.cerevisiae containing granules of glycogen, for different periods of storage at low temperature

$\square$ - the number of fresh yeast cells after 1 day of storage at $2 \pm 2{ }^{\circ} \mathrm{C}$;

- the number of yeast cells after 21 days of storage at $2 \pm 2{ }^{\circ} \mathrm{C}$.

No significant differences have been revealed in protein SH- and SS- groups in the supernatant liquid obtained from the fresh yeast and after 7 days of storage and also within intervals of 14-21 and 28-35 days of storage. The amount of protein in the supernatant liquid of fresh yeasts was of $1.04 \pm 0.06 \mathrm{~g} \mathrm{~L}^{-1}$ and decreased to $0.81 \pm 0.03 \mathrm{~g} \mathrm{~L}^{-1}$ after 35 days of storage. The average concentrations of $\mathrm{SH}-$ and SS- groups in water-soluble proteins $\left(\mu \mathrm{mol} \mathrm{g} \mathrm{g}^{-1}\right)$ and in low-molecular substances $\left(\mu \mathrm{mol} \mathrm{L} \mathrm{L}^{-1}\right)$ for different periods of the storage was as follows: 1 after 0-7 days; 2 after 14-21days; 3 after 28-35 days.

Table 1

Concentrations of reduced (SH) and oxidized (SS) thiol groups in water extracts of yeast

\begin{tabular}{lcccc}
\hline \multirow{2}{*}{ Thiol compounds } & \multicolumn{3}{c}{ Time of storage, days } \\
\cline { 3 - 5 } & & $\mathbf{0}-\mathbf{7}$ & $\mathbf{1 4 - 2 1}$ & $\mathbf{2 8}-\mathbf{3 5}$ \\
\hline $\begin{array}{l}\text { Protein's, } \\
\mu \mathrm{mol} \cdot \mathrm{g}^{-1}\end{array}$ & $\mathrm{SH}$ & $353 \pm 22$ & $352 \pm 23$ & $243 \pm 31$ \\
$\begin{array}{l}\text { Low- } \\
\text { molecular, } \\
\mu \text { mol L }\end{array}$ & SH & $147 \pm 10$ & $139 \pm 15$ & $129 \pm 19$ \\
\hline
\end{tabular}

According to the data obtained, the amount of $\mathrm{SH}$ - groups in the proteins of yeast water extracts decreased by $31 \%$ after 35 days of storage (from 353.41 to $243.15 \mu \mathrm{mol} \mathrm{g}^{-1}$ ), and the amount of SS-groups did not significantly change (147.52 and $129.36 \mu \mathrm{mol} \mathrm{g}^{-1}$ respectively). Under the same conditions, the amount of low-molecular SH-groups doubled (from 60.29 to $120.45 \mu \mathrm{mol} \mathrm{L} \mathrm{L}^{-1}$ ) and the amount of SS- groups did not have any significant changes (36.18 and $39.29 \mu \mathrm{mol} \mathrm{L} \mathrm{L}^{-1}$, respectively). There were proposed several possible reasons for an increase of the amount of low-molecular thiol compounds in yeast cells under low-temperature storage when cannot be an efficient anabolism. The first reason could be a decrease in utilization of reduced glutathione for intracellular metabolic reactions which go slower due to a low temperature. The second one is a possible activation of partial proteolysis of intracellular proteins that create lowmolecular peptides with a high concentration of cysteine containing SH- groups. An intense expression of metallothioneins in yeast S. cerevisiae DV 747 including a high amount of sulfur containing amino acids, up to $30 \%$ per mol of protein, and resistance to active oxygen, appears to confirm the latter mechanism (Nakamura, 2004). It can be assumed that yeast cells were under a starvation stress, which leads to activation of free radical oxidation processes and antioxidant defense mechanisms. The obtained increase of watersoluble low-molecular thiols during the storage of yeast at low temperatures can occur due to the response of cells to the unfavorable environmental factors. Further research is planned to investigate the mechanism of accumulating reduced low-molecular thiol compounds in yeast cells during the storage and to take an attempt of revealing the factors which affect this mechanism.

\section{Conclusions}

A close connection is known to exist between morphologic and physiologic states of cells. The cell size and cell shape are determined by genetic and physiological properties of biological objects and also by environmental conditions. The cell ability to react to different external factors makes it possible to use these cells as biosensors. The experiment results have shown a long-term effect of low temperature on $S$. cerevisiae yeast population adaptive morphological and biochemical modifications in the cells. The most important result of the present study was a small decrease (by 20\%) in the amount of medium yeast cells $(5-7 \times 10-12 \mu \mathrm{m})$ at low temperatures. A 4-time increase in the amount of budding cells by and an increase in the amount of dead cells demonstrated a decrease in the physiological activity of yeast cells. A decrease in the amount of protein thiol compounds (by $31 \%$ ) and a simultaneous 2-fold increase in the number of low-molecular thiols were the most significant changes in yeast cells. The results obtained may need some further research and some theoretical analysis in order to fully explore the possibilities of their prospective practical applications. 


\section{References}

1. Baronian K.H.R., Gurazada S. (2007) Electrochemical detection of wild type Saccharomyces cerevisiae responses to estrogens. Biosensors and Bioelectronics, Vol. 22, p. 2493-2499.

2. Coelho M., Dereli A., Haese A., Kuhn S., Malinovska L., DeSantis M., Shorter J., Alberti S., Gross T., TolicNørrelykke I. (2013) Fission yeast does not age under favorable conditions, but does so after stress. Current Biology, Vol. 23, p. 1844-1852.

3. Deere D., Shen J., Vesey G., Bell P., Bissinger P., Vea D. (1998) Flow cytometry and cell sorting for yeast viability assessment and cell selection. Yeast, Vol. 14, p. 147-160.

4. Flohe L. (2010) Changing paradigms in thiology: from antioxidant defense toward redox regulation. In: Methods in Enzymology. Vol. 473. Thiol Redox Transitions in Cell Signaling, Part A.: Chemistry and Biochemistry of Low Molecular Weight and Protein Thiols. 1st ed. E. Cadenas, L. Packer (eds). London: Academic Press, p. 1-39.

5. Ksenzhek O.S., Petrova S.A. (1984) Электрохимические свойства обратимых ред-окс систем. [Electro chemical properties of reversible red-ox systems].Moscow: Nauka, 250 p. (in Russian).

6. Leung-Toung R., Li W., Tam T., Karimian K. (2002) Thiol-dependent enzymes and their inhibitors: A review. Current Medicine Chemistry, Vol. 9(9), p. 979-1002.

7. Liu H., Lightfoo R., Stevens J. (1996) Activation of heat shock factor by alkylating agents is triggered by glutathione depletion and oxidation of protein thiols. Journal of Biology and Chemistry, Vol. 271(9), p. 4805-4812.

8. Lowry O.H., Rosenbrough N.J., Farr A.L., Randall R.J. (1951) Protein measurement with the Folin phenol reagent. Journal of Biology and Chemistry, Vol. 193(1), p. $265-275$.

9. Mattanovich D., Borth N. (2006) Applications of cell sorting in biotechnology. Microbial Cell Factories. Vol. 5, p. 12-17.
10. Munday R., Winterbourn C. (1989) Reduced glutathione in combination with superoxide dismutase as an important biological antioxidant defense mechanism. Biochemistry Pharmacology, Vol. 38(24), p. 4349-4352.

11. Müller S., Lösche A. (2004) Population profiles of a commercial yeast strain in the course of brewing. Journal of Food Engineering, Vol. 63, p. 375-381.

12. Nakamura H. (2004) Thioredoxin as a key molecule in redox signaling. Antioxid. Redox Signal, Vol. 6(1), p. 15-17.

13. Petit P., Glab N., Marie D., Kieffer H., Metezeau P. (1996) Discrimination of respiratory dysfunction in yeast mutants by confocal microscopy, image, and flow cytometry. Cytometry, Vol. 23, p. 28-38.

14. Schafer F., Buettner G. (2001) Redox environment of the cell as viewed through the redox state of the glutathione disulfide/glutathione couple. Free Radicical Biol. Med., Vol. 30 (11), p. 1191-1212.

15. Schreuder M.P., Mooren A.T., Toschka H.Y., Verrips C.T., Klis F.M. (1996) Immobilizing proteins on the surface of yeast cells. Trends Biotechnology, Vol. 14, p. $115-120$.

16. Sokolovskij V.V. (1962) Определение сульфгидрильных групп в крови амперометрическим титрованием [Determination of sulfhydryl groups in the blood by amperometric titration]. Lab. Delo, Vol. 8, p. 3-6 (in Russian).

17. Sokolovskij V.V. (2008) Тиолдисульфидная система в рекции организма на факторы окружающей среды [Thiol disulfide system in the body's reaction to environmental factors] St. Petersburg: Nauka, 112 p. (in Russian).

18. Zhilinskaia N.T., Bazarnova J.G., Shleikin A.G., Peshuk L.V., Galenko O. (2016) Using of bioinformatics and computer morphometry in study of Fusarium spp. causing potato dry rot. Ukrainian Food Journal, Vol. 5(3), p. 515-522 (in Russian). 